\title{
A type of Mantle-derived hydrothermal dolomite in a Permian Rift Basin
}

\footnotetext{
Xin JiaO, Yiqun LiU, Hong Li, Dingwu ZhOU

Department of Geology, Northwest University, jxin807@163.com

Subaqueous volcanic-hydrothermal field is a complex hybrid geological system, where sediments originated from underground, terrestrial, and biotic sources are mixed. Here we propose a possible primary origin of dolomite in a interpreted sediment-hosted geothermal system in a lacustrine environment, where hydrothermal, volcanic, and biotic domains interact. The dolomite occurs in middle-Permian Lucaogou Fm., Santanghu Basin, NW China, which was an intracontinental rift basin and contains a lot of hydrothermalvolcanic build-ups from seismic sections. The fm. is main laminated dolostones interbedding with tuffaceous shales. The dolostones are composed of dolomite ( $77 \%$ on average) and pyroclastics (quartz, alkaline feldspars, and analcimes). Dolomite crystals are commonly less than $3 \mu \mathrm{m}$ in size, mainly anhedral to subhedral with a low degree of stoichiometry. The pyroclastics are angular, shard-like, bedding parallel, and show normal grading in dolomitedominated laminae, indicating a volcanic origin during deposition and precipitation. Unique nanoscale filamentary minerals and build-up structures were observed at intercrystalline pores of dolomite and laminae of dolostones in some samples, respectively. And $\delta{ }^{13} \mathrm{C}$ (5.2\% to 9.9\%, $6.9 \%$ on average) of dolomite suggests the formation of dolomites was affected by the generation of bacterial participating methane. $\delta{ }^{18} \mathrm{O}(-1 \%$ o to $-17.4 \% 0,-7.5 \%$ on average) values of dolostones composed of subhedral dolomite are more negative than those of anhedral ones, which indicate recrystallization by hydrothermal activities. The whole rock strontium isotope values $(0.70462$ to 0.70525 , 0.70501 on average) and $\delta \mathrm{Mg}(-0.89$ to $-0.24,-0.52$ on average) values indicate that the sedimentary fluids may be derived from mantle. The dolostone is a rare type of microbially-influenced dolostone related to hydrothermal and volcanic activities. Repetitive volcanic-hydrothermal activities raised the temperature unevenly on the lake floor, which broke the threshold dynamic barrier temperature $\left(\sim 50^{\circ} \mathrm{C}\right)$. Hydrothermal fluids which reacted with mantleoriginated magma and wall rocks provided abundant $\mathrm{Mg}$. Thermophilic microbes near the hydrothermal vents multiplied rapidly, generating a favorable chemical condition for dolomite precipitation. This work shows a mixed geothermal system related to subaqueous volcanism in an ancient lake sedimentation.
} 